\title{
Carbon-arsenic bond cleavage by a newly isolated Gram-negative bacterium, strain ASV2
}

\author{
John P. Quinn and Geoffrey McMullan†
}

Author for correspondence: John P. Quinn. Tel: +44 1232245133 ext. 2287/2250. Fax: +44 1232236505.

School of Biology and Biochemistry, Queen's University of Belfast, Medical Biology Centre, 97 Lisburn Road, Belfast BT9 7BL, Northern Ireland

\begin{abstract}
Strain ASV2, an unidentified Gram-negative bacterium newly isolated from activated sludge, was found to utilize arsonoacetate at concentrations up to at least $30 \mathrm{mM}$ as sole carbon and energy source, with essentially quantitative extracellular release of arsenate. Cell-free conversion of arsonoacetate could not be obtained, but resting-cell studies indicated that the carbon-arsenic bond cleavage activity was inducible in the presence of arsonoacetate and was of limited substrate specificity, also breaking down arsonochloroacetate. The inorganic product of the reaction may be arsenite since an inducible arseniteoxidizing activity was also found in arsonoacetate-metabolizing cells. This is the first report of a micro-organism capable of utilizing a compound containing the carbon-arsenic bond. The results indicate that the ability of bacteria to degrade arsonoacetate is not fortuitous and may be found in environments not previously exposed to organoarsenicals.
\end{abstract}

Keywords: arsenate, arsenite, organometalloid, organoarsenical, Pseudomonas diminuta

\section{INTRODUCTION}

The metalloid arsenic, 20th most common element in the earth's crust, is chemically similar to phosphorus, also in group 15 of the elements. Thus bioalkylated forms of arsenic are distributed widely (cf. organophosphonates). Such arsenical compounds may arise from the need of organisms to protect themselves from the uncoupling effects of arsenate, which they cannot avoid taking in by their phosphate-concentrating mechanisms. The fact that arsenate is much more easily reduced than phosphate may make the observed alkylations possible. Examples of bioalkylated products include methylarsonic and dimethylarsinic (cacodylic) acids, which are predominant in terrestrial environments, and more complex species such as arsenobetaine, arsenocholine, and arsenolipids and arsenosugars, which are abundant in marine ecosystems (Andreae, 1986; Edmonds \& Francesconi, 1987; Cullen \& Reimer, 1989; Francesconi \& Edmonds, 1993).

In addition, xenobiotic compounds containing the $\mathrm{C}-\mathrm{As}$ bond still enter the environment in a variety of agricultural applications - some 11000 tonnes annually in the United States (Abernathy, 1983). Most significant are the continuing uses of arsanilic acid, 3-nitro-4-hydroxyphenylarsonic acid and 4-nitrophenylarsonic acid as animal feed additives, and of dimethylarsinic acid, and the mono- and di-sodium salts of methylarsonic acid, as cotton defoliants

†Present address: School of Biology, University of Ulster, Cromore Road, Coleraine BT52 1SA, Northern Ireland. and post-emergence grass herbicides, respectively (Andreae, 1986; Tamaki \& Frankenberger, 1992).

Although extensive research has been undertaken on the mechanisms, and the extent, of bioalkylation of arsenic (reviewed by Thayer, 1993; Gadd, 1993) much less is known about the environmental fate of organoarsenicals, and a lack of information on the mechanisms of C-As bond cleavage constitutes the weakest link in our understanding of the biogeochemical cycling of the element. The process is attributed exclusively to microbial activity (Andreae, 1986); thus the co-metabolism of arsenobetaine by marine sedimentary bacteria has been demonstrated, although the compound did not itself support bacterial growth (Hanaoka et al., 1987, 1991, 1992). Similarly, the slow mineralization of methylarsonate to arsenate and $\mathrm{CO}_{2}$ by a number of genera of soil bacteria has been described, although such demethylation occurred only in a yeast-extract- or acetate-based medium (Von Endt et al., 1968; Shariatpahani et al., 1983). To our knowledge, however, in no instance has any micro-organism capable of the utilization of an organoarsenical as sole carbon and energy source yet been reported. Nor is any information available on the enzymology of the $\mathrm{C}-\mathrm{As}$ bond cleavage reaction; for example, the $\mathrm{C}-\mathrm{P}$-bond-cleaving enzymes phosphonoacetaldehyde hydrolase and phosphonoacetate hydrolase show no activity towards their arsonate analogues (Lacoste et al., 1992; McMullan \& Quinn, 1994).

We now describe the utilization of arsonoacetate $\left(\mathrm{H}_{2} \mathrm{O}_{3} \mathrm{AsCH} \mathrm{H}_{2} \mathrm{COOH}\right)$, a model compound containing the 
C-As bond, as sole carbon and energy source by a newly isolated bacterium, and report an in vivo investigation of the $\mathrm{C}-\mathrm{As}$ bond cleavage activity implicated.

\section{METHODS}

Isolation of an arsonoacetate-degrading bacterium. Basal enrichment culture medium contained the following ( $\mathrm{g}$ per $\mathrm{l}$ of distilled water): $\left(\mathrm{NH}_{4}\right)_{2} \mathrm{SO}_{4}, 1 \cdot 0 ; \mathrm{KCl}, 0 \cdot 2 ; \mathrm{MgSO}_{4} .7 \mathrm{H}_{2} \mathrm{O}, 0 \cdot 2$; $\mathrm{CaCl}_{2} .2 \mathrm{H}_{2} \mathrm{O}, 0.001$; ferric ammonium citrate, 0.001 ; yeast extract, 0.015 ; plus vitamin solution, $1.0 \mathrm{ml} \mathrm{l}^{-1}$, and trace element solution, $1.0 \mathrm{ml} \mathrm{l}^{-1}$ (both $\mathrm{Krieg}, 1981$ ). The $\mathrm{pH}$ was adjusted to $7 \cdot 2$ and the medium sterilized by filtration. Filtersterilized arsonoacetate was routinely added from a $50 \mathrm{mM}$ stock solution ( $\mathrm{pH} 7 \cdot 2$ ) to give a final concentration in the medium of $5 \mathrm{mM}$, and $100 \mathrm{mM}$ phosphate buffer ( $\mathrm{pH} \mathrm{7.2)}$ was added to a final concentration of $0.1 \mathrm{mM}$. When other arsonoacetate concentrations were supplied the $C:$ As: $P$ ratio was maintained at $100: 50: 1$.

Enrichment culture was carried out using a $0.5 \%(\mathrm{v} / \mathrm{v})$ inoculum from an activated sludge plant treating a mixture of domestic and industrial laundry wastes (Dunmurry, Northern Ireland). Erlenmeyer flasks $(250 \mathrm{ml})$ containing $35 \mathrm{ml}$ inoculated medium were incubated at $27^{\circ} \mathrm{C}$ on a rotary shaker (100 r.p.m.). Growth of cultures was followed by measuring their attenuance at $650 \mathrm{~nm}\left(D_{650}\right)$. Supernatant from the enrichment was periodically assayed colorimetrically for arsenate release as described by Phillips \& Taylor (1976), and the presence of arsenite determined qualitatively by paper electrophoresis or TLC (Lacoste et al., 1992; Von Endt et al., 1968).

After five serial transfers in the same medium, followed by two transfers at an arsonoacetate concentration of $10 \mathrm{mM}$, a sample $(50 \mu \mathrm{l})$ of the enrichment culture was plated on solidified medium containing $1.2 \%(\mathrm{w} / \mathrm{v})$ Bactoagar (Difco). Plates were incubated at $27^{\circ} \mathrm{C}$ for $7 \mathrm{~d}$ and the ability of morphologically distinct colonies to use arsonoacetate in liquid culture was further tested.

Pure cultures of the single bacterial isolate thus obtained were subsequently grown in liquid medium under the same conditions; a stock culture of the isolate was maintained on solidified, arsonoacetate-containing medium.

Identification of isolate ASV2. The Gram stain and oxidase test were carried out by standard procedures (Collins \& Lyne, 1976). The isolate was further characterized using an API 2ONE bacterial identification kit (Analytab Products), and also examined at the National Collections of Industrial and Marine Bacteria, Aberdeen, UK.

Chemicals. $p$-Arsanilic acid, dimethylarsinic acid and phenylarsonic acid were obtained from Aldrich and the disodium salt of sulphoacetic acid from Kodak Laboratory and Research Chemicals. Arsenobetaine and 2-(dimethylarsoryl)ethanol were gifts from Dr K. A. Francesconi, Western Australian Marine Research Laboratories, North Beach, Western Australia. 2Aminoethylarsonic acid was a gift from Dr H. B. F. Dixon, University of Cambridge, UK, and was prepared from 2chloroethylarsonic acid by the method of Geoghegan \& Dixon (1989), by treating it with 2-aminoethanol to obtain $\mathrm{HO}-\mathrm{CH}_{2}-\mathrm{CH}_{2}-\mathrm{NH}-\mathrm{CH}_{2}-\mathrm{CH}_{2}-\mathrm{AsO}_{3} \mathrm{H}_{2}$, and then with periodate. Methylarsonic acid, also a gift from Dr H. B. F. Dixon, was prepared as the disodium salt by treating iodomethane with alkaline arsenite (Quick \& Adams, 1922). The syntheses of arsonoacetic acid and dibromomethylarsonic acid, the cyclohexylammonium salt of chloromethylarsonic acid, and the bis(cyclohexylammonium) salt of arsono(chloro)acetic acid are reported in the appendix to this paper (Sparkes \& Dixon, 1995). All other chemicals were obtained from Sigma and were of highest available purity.

In vitro enzyme assays. Cells grown on $30 \mathrm{mM}$ arsonoacetate, $30 \mathrm{mM}$ acetate, or $30 \mathrm{mM}$ acetate plus $5 \mathrm{mM}$ arsenite (added $4 \mathrm{~h}$ before harvesting), were harvested by centrifugation in the late exponential phase $\left(12000 \mathrm{~g}\right.$ for $15 \mathrm{~min}$ at $\left.4{ }^{\circ} \mathrm{C}\right)$, washed in basal salts medium lacking a carbon source, and disrupted ultrasonically at $16 \mathrm{kHz}$ on ice for $5 \mathrm{~min}$, in the presence and absence of $0.1 \mathrm{mM}$ dithiothreitol ( $30 \mathrm{~s}$ sonication followed by $2 \mathrm{~min}$ cooling). The homogenate was centrifuged $(25000 \mathrm{~g}$ for $30 \mathrm{~min}$ at $4{ }^{\circ} \mathrm{C}$ ) and dialysed overnight against $50 \mathrm{mM} \mathrm{Tris} / \mathrm{HCl}$ $(\mathrm{pH} 7 \cdot 2)$. Protein concentrations were measured by the method of Bradford (1976).

$\mathrm{C}-$ As bond cleavage activity was assayed at $30^{\circ} \mathrm{C}$ in a $1.0 \mathrm{ml}$

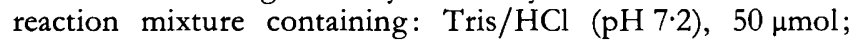
arsonoacetate, $5 \mu \mathrm{mol}$; cell extract, $0.5 \mathrm{mg}$ protein. The reaction was initiated by the addition of cell extract, and terminated by addition of $0.2 \mathrm{ml} 50 \%(\mathrm{w} / \mathrm{v})$ trichloroacetic acid. After the removal of precipitate by centrifugation, supernatants were assayed for arsenate and arsenite as described above, and for acetate using an enzyme-based Acetate Test Kit (Boehringer Mannheim) with a lower detection limit of $10 \mu \mathrm{g} \mathrm{ml}^{-1}$. Glycollate was determined by the colorimetric method of Calkins (1943), based on its reaction with 2,7-dihydroxynaphthalene in acid solution.

Arsenite-oxidizing activity in cell extracts was assayed similarly, but with $5 \mu \mathrm{mol}$ sodium arsenite replacing arsonoacetate as substrate; arsenate levels were determined in assay supernatants.

Resting cell assays. Levels of $\mathrm{C}-\mathrm{As}$ bond cleavage activity and arsenite-oxidizing activity were routinely determined by restingcell assays. Cells of strain ASV2 were grown to late exponential phase on $30 \mathrm{mM}$ arsonoacetate (or other substrate as specified), harvested by centrifugation $\left(12000 \mathrm{~g}\right.$ for $15 \mathrm{~min}$ at $4^{\circ} \mathrm{C}$ ), washed twice in basal medium lacking a carbon source, and resuspended in the same medium to a known concentration (approximately $2 \mathrm{mg}$ fresh weight cells $\left.\mathrm{ml}^{-1}\right)$. Samples $(2.5 \mathrm{ml})$ of this cell suspension were added to $2.5 \mathrm{ml}$ of a solution $(\mathrm{pH} \mathrm{7.2)}$ ) of the test substrate (normally arsonoacetate or sodium arsenite) to give a final substrate concentration of $5 \mathrm{mM}$. Assays were carried out in $30 \mathrm{ml}$ vials incubated with gentle shaking at $27^{\circ} \mathrm{C}$; C-As bond cleavage activity and arsenite-oxidizing activity were measured by determination of arsenate levels in assay supernatants over a period (normally between 0.5 and $3 \mathrm{~h}$ ) when arsenate release rates were linear. Control assays, from which either substrate or cell suspension had been omitted, were carried out in parallel. All substrates were stable under the assay conditions used.

\section{RESULTS}

\section{Isolation and characterization of organism}

After prolonged enrichment (seven serial transfers over a period of 22 weeks) a single organism, as judged on the basis of colonial morphology, was found to be able to use arsonoacetate as sole carbon and energy source. The isolate, designated as ASV2, was Gram-negative, motile, non-fermentative, weakly oxidase- and catalase-positive, and formed visible buff/off-white colonies, no greater than $0.4 \mathrm{~mm}$ in diameter, after 5 to $6 \mathrm{~d}$ at $30^{\circ} \mathrm{C}$ on either arsonoacetate-containing mineral salts medium or nutrient agar. It did not grow at 37 or $45^{\circ} \mathrm{C}$, was unable to 


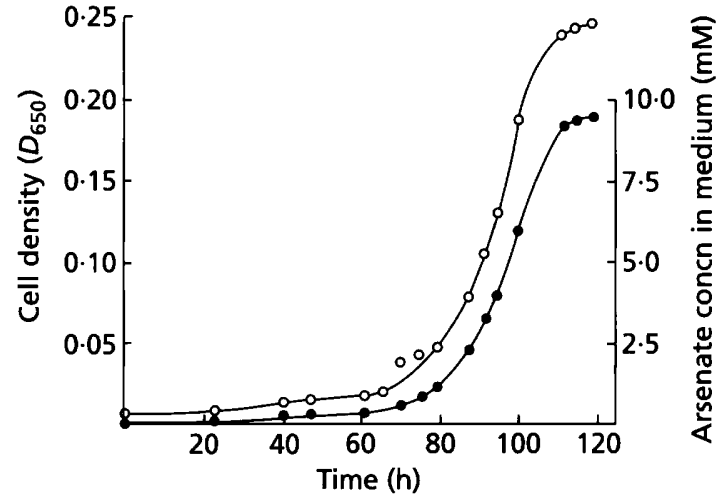

Fig. 1. Grown of strain ASV2 $(O)$ and arsenate release $(0)$ on a medium containing $10 \mathrm{mM}$ arsonoacetate as sole carbon and energy source.

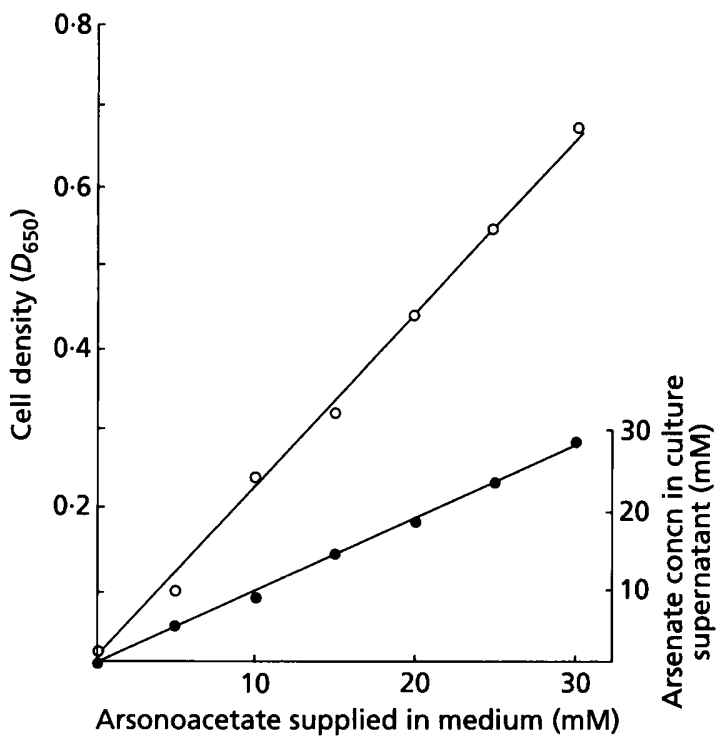

Fig. 2. Cell yield of strain ASV2 (O) and supernatant arsenate levels (O) following growth of the organism for $120 \mathrm{~h}$ on a medium containing varying concentrations of arsonoacetate as sole carbon and energy source.

produce acid from glucose, reduce nitrate, or hydrolyse gelatin, urea or aesculin, and did not possess the following enzymes: DNase, arginine dihydrolase, $\beta$-galactosidase and phenylalanine deaminase. The isolate assimilated acetate, malate, propionate and (weakly) $\beta$-hydroxybutyrate but was unable to assimilate $N$-acetylglucosamine, adipate, alanine, decanoate, citrate, gluconate, glucose, maltose, mannitol, mannose and phenylacetate. On the basis of these largely negative physiological characteristics it was not possible to identify isolate ASV2; it most closely resembled Pseudomonas diminuta, but differed in its ability to assimilate malate and propionate and in its inability to grow at $37^{\circ} \mathrm{C}$. Pseudomonas diminuta has recently been reclassified as Brevundimonas diminuta (Segers et al., 1994).
Table 1. C-As bond cleavage and arsenite-oxidizing activities in resting cells of strain ASV2 pregrown under different conditions

\begin{tabular}{|lcc|}
\hline $\begin{array}{c}\text { Substrate for pre-growth } \\
\text { of cells }\end{array}$ & $\begin{array}{c}\text { Activity } \\
\text { [nmol arsenate released } \\
\left.\mathbf{h}^{-1} \text { (mg cells) }^{-1}\right]^{*}\end{array}$ \\
\cline { 2 - 3 } & $\begin{array}{c}\text { C-As bond } \\
\text { cleavage }\end{array}$ & $\begin{array}{c}\text { Arsenite } \\
\text { oxidation }\end{array}$ \\
\hline $\begin{array}{l}\text { Arsonoacetate }(30 \mathrm{mM}) \\
\text { Acetate }(30 \mathrm{mM})\end{array}$ & $1120 \pm 8$ & $1950 \pm 14$ \\
Acetate $(30 \mathrm{mM})+$ arsenite & $1 \pm 1$ & $1 \pm 1$ \\
$(5 \mathrm{mM}) \dagger$ & $8 \pm 1$ & $1000 \pm 12$ \\
\hline
\end{tabular}

* Each value is the mean of triplicate assays \pm standard error of the mean.

† Arsenite was added $4 \mathrm{~h}$ before cells were harvested.

\section{Growth of organism}

Growth of the isolate on $10 \mathrm{mM}$ arsonoacetate as sole carbon and energy source, and concomitant release of arsenate into the culture supernatant, are shown in Fig. 1; the presence of arsenite in supernatants could not be detected by chromatography, but total disappearance of arsonoacetate from the growth medium by $120 \mathrm{~h}$ was confirmed. An uninoculated control experiment showed that arsenate was not spontaneously released from arsonoacetate over the period of incubation. Final cell yields were directly proportional to the level of arsonoacetate supplied, up to at least $30 \mathrm{mM}$ (Fig. 2). Growth was accompanied by the release of $>95 \%$ arsonoacetate arsenic as arsenate.

Besides arsonoacetate, which supported a mean cell doubling time $\left(t_{\mathrm{d}}\right)$ of $9.6 \mathrm{~h}$, strain ASV2 could utilize acetate $\left(t_{\mathrm{d}} 6.9 \mathrm{~h}\right)$ and sulfoacetate $\left(t_{\mathrm{d}} 11.1 \mathrm{~h}\right)$, but failed to grow on phosphonoacetate, malonate or glyoxylate. Glycollate supported weak growth; cell yield was $<10 \%$ that on acetate after a $191 \mathrm{~h}$ lag phase (compared to $35 \mathrm{~h}$ for acetate). The following organoarsenicals (all at $5 \mathrm{mM}$ ) failed to support growth: 2-aminoethylarsonic acid, phenylarsonic acid, $p$-arsanilic acid, dibromomethylarsonic acid, chloromethylarsonic acid (cyclohexylammonium salt), arsonochloroacetic acid [bis(cyclohexylammonium) salt], methylarsonic acid (disodium salt) dimethylarsinic acid, arsenobetaine (trimethylarsonioacetate), 2-(dimethylarsoryl)ethanol.

\section{In vitro assay of C-As bond cleavage activity}

To examine C-As bond cleavage activity in greater detail, attempts to obtain cell-free activity were made. Despite the addition of cofactors (NADH, NADPH, FMN, FAD, Coenzyme A), metal ions $\left(\mathrm{Zn}^{2+}, \mathrm{Mg}^{2+}, \mathrm{Mn}^{2+}, \mathrm{Fe}^{3+}\right)$, or yeast extract, in vitro $\mathrm{C}-\mathrm{As}$ bond cleavage activity on arsonoacetate was never observed in extracts of arsonoacetate-grown cells. However, such extracts contained low levels of arsenite-oxidizing activity in the 
Table 2. Specificity of C-As bond cleavage by resting cells of strain ASV2 pregrown on arsonoacetate

\begin{tabular}{|lc|}
\hline Assay substrate (5 $\mathbf{m M})$ & $\begin{array}{c}\text { C-As bond } \\
\text { cleavage activity* } \\
\text { [nmol arsenate } \\
\text { released } \mathbf{~ h}^{-1} \\
\left.\text { (mg cells) }^{-1}\right]^{*}\end{array}$ \\
\hline Arsonoacetic acid & $280 \pm 9$ \\
Chloromethylarsonic acid \\
(cyclohexylammonium salt) \\
Arsonochloroacetic acid \\
[bis(cyclohexylammonium) salt] \\
Methylarsonic acid (disodium salt) \\
2-Aminoethylarsonic acid
\end{tabular}

* Each value is the mean of triplicate assays \pm standard error of the mean. No activity was observed on dibromomethylarsonic acid, $p$-arsanilic acid, dimethylarsinic acid, phenylarsonic acid, arsenobetaine (trimethylarsonioacetate) or 2-(dimethylarsoryl)ethanol, each at $5 \mathrm{mM}$.

absence of any addition; typical values were in the order of $0.2 \mathrm{nmol}$ arsenate produced $\mathrm{min}^{-1}(\mathrm{mg} \text { protein })^{-1}$.

\section{In vivo assay of C-As bond cleavage activity}

Subsequent investigation of $\mathrm{C}-$ As bond cleavage activity in resting-cell suspensions of isolate ASV2 (Table 1) showed that the activity was inducible by arsonoacetate. In addition, cells metabolizing arsonoacetate contained high levels of arsenite-oxidizing activity, which was also inducible in the presence of arsenite (Table 1). No evidence of transient extracellular accumulation of acetate was obtained.

The substrate specificity of the C-As bond cleavage activity present in arsonoacetate-grown cells was examined using a range of xenobiotic and biogenic organoarsenicals (Table 2). Higher activities were obtained with the arsonoacetate analogue arsonochloroacetate $\left(\mathrm{HOOC}-\mathrm{CHCl}-\mathrm{AsO}_{3} \mathrm{H}_{2}\right)$ than on arsonoacetate itself. This is despite the fact that the isolate is unable to utilize the compound as a carbon source, presumably since it is unable to dechlorinate the product of $\mathrm{C}-\mathrm{As}$ bond cleavage; chloroacetate, for example, did not serve as a growth substrate. Significant levels of arsenate release were not obtained from any other substrate, and no activity whatsoever was observed on arylarsonates and those compounds containing more than one $\mathrm{C}-\mathrm{As}$ bond.

\section{DISCUSSION}

This is the first report of a micro-organism capable of the utilization and mineralization of a compound containing the $\mathrm{C}-\mathrm{As}$ bond. Although similar enrichments have not been carried out on other environmental samples, our findings suggest that the ability may be widespread possibly even limited by the ability of cells to deal with a toxic cleavage product. In this instance at least, the inducibility of the activity also implies that $\mathrm{C}-\mathrm{As}$ bond cleavage is not fortuitous. This is surprising, since the strain responsible was isolated from an environment apparently lacking significant prior exposure to organoarsenicals, while neither of the compounds that were the principal substrates of its $\mathrm{C}-\mathrm{As}$ bond cleavage activity is known to occur in nature, or to be of industrial or agricultural significance. Indeed the synthesis of arsonochloroacetate has not previously been reported.

In view of our inability to detect in vitro $\mathrm{C}-\mathrm{As}$ bond cleavage activity in cells of isolate ASV2, speculation on the nature of the cleavage reaction must be tentative. The fact that arsenite-oxidizing activity is induced simultaneously, however, suggests that unlike the cleavage of the C-P bond by phosphonoacetate hydrolase (McMullan \& Quinn, 1994), the mechanism may be reductive so that arsenite rather than arsenate is produced; in vitro activity would be unlikely if the reducing agent involved were an insoluble or membrane-bound flavoprotein. Phosphite has, in fact, been implicated as an intermediate in the cleavage of the $\mathrm{C}-\mathrm{P}$ bond by $\mathrm{C}-\mathrm{P}$ lyase (Metcalf \& Wanner, 1991) but in vitro activity of this enzyme complex has not yet been obtained (McMullan et al., 1991), although the products of nine genes are believed to be essential (Wanner \& Metcalf, 1992).

Arsenite is often 100 to 200 times more toxic than arsenate (Williams \& Silver, 1984), since it blocks dithiols with great affinity whereas arsenate merely uncouples phosphorylation reactions. For cells of isolate ASV2, grown on an acetate-based medium, the MIC for arsenite was $5 \mathrm{mM}$, but under the same conditions an arsenate concentration of $200 \mathrm{mM}$ was not inhibitory (in each case an As: $P$ ratio of 50:1 was maintained; results not shown). The oxidation of arsenite to arsenate may thus be an effective means of arsenite detoxification, as suggested by Williams \& Silver (1984). This activity has been demonstrated in a number of bacteria (Green, 1918; Turner \& Legge, 1954; Osborne \& Ehrlich, 1976; Phillips \& Taylor, 1976; Sehlin \& Lindstrom, 1992) and an inducible arsenite oxidase located on the outer surface of the inner cell membrane has recently been purified from Alcaligenes faecalis (Anderson et al., 1992).

It seems most likely that arsenic is subsequently exported from the cells of strain ASV2 in the form of arsenate; for this process an arsonoacetate/arsenate antiporter would seem a feasible mechanism, by analogy with the organophosphate/orthophosphate antiporter described in several bacteria (Cook, 1988). By contrast, it has now been established that plasmid-encoded arsenic resistance in Escherichia coli and Staphylococcus aureus involves the reduction of arsenate to arsenite; the latter is then exported from the cells by an energy-dependent efflux process (Ji \& Silver, 1992).

The nature of the organic product of $\mathrm{C}-\mathrm{As}$ bond cleavage in arsonoacetate by strain ASV2 remains uncertain, although the poor growth of the organism on glycollate, and its inability to utilize glyoxylate - albeit supplied exogenously - suggest that it may be acetate. Cell yields of the organism on acetate were consistently some $12 \%$ 
higher than those on arsonoacetate at the corresponding concentration.

\section{ACKNOWLEDGEMENT}

We thank Dr H. B. F. Dixon for the gift of potential substrates and for his generous advice and encouragement.

\section{REFERENCES}

Abernathy, J. R. (1983). Role of arsenical chemicals in agriculture. In Arsenic: Industrial, Biomedical, Environmental Perspectives, pp. 57-62. Edited by W. H. Lederer \& R. J. Fensterheim. New York: Van Nostrand Reinhold.

Anderson, G. L., Williams, J. \& Hille, R. (1992). The purification and characterization of arsenite oxidase from Alcaligenes faecalis, a molybdenum-containing hydroxylase. $J$ Biol Chem 267, 2367423682.

Andreae, M. O. (1986). Organoarsenic compounds in the environment. In Organometallic Compounds in the Environment: Principles and Reactions, pp. 198-228. Edited by P. J. Craig. Harlow: Longman.

Bradford, M. M. (1976). A rapid and sensitive method for the quantitation of microgram quantities of protein utilizing the principle of protein-dye binding. Anal Biochem 72, 248-254.

Calkins, V. P. (1943). Microdetermination of glycolic and oxalic acids. Ind Eng Chem 15, 762-763.

Collins, C. H. \& Lyne, P. M. (1976). Biochemical methods. In Microbiological Methods, pp. 167-178. Edited by C. H. Collins \& P. M. Lyne. London: Butterworths.

Cook, A. M. (1988). Combined carbon and phosphorus or carbon and sulphur substrates. In Mixed and Multiple Substrates and Feedstocks, pp. 71-83. Edited by G. Hamer, T. Egli \& M. Snozzi. Konstanz: European Biotechnology Federation.

Cullen, W. R. \& Reimer, K. J. (1989). Arsenic speciation in the environment. Chem Rev 89, 713-764.

Edmonds, J. S. \& Francesconi, K. A. (1987). Transformations of arsenic in the marine environment. Experientia 43, 553-557.

Francesconi, K. A. \& Edmonds, J. S. (1993). Arsenic in the sea. Oceanogr Mar Biol Annu Rev 31, 111-151.

Gadd, G. M. (1993). Microbial formation and transformation of organometallic and organometalloid compounds. FEMS Microbiol Rev 11, 297-316.

Geoghegan, K. F. \& Dixon, H. B. F. (1989). Synthesis of 2aminoethylarsonic acid. A new synthesis of primary amines. Biochem J 260, 295-297.

Green, H. H. (1918). Description of a bacterium which oxidizes arsenite to arsenate, and of one which reduces arsenate to arsenite, isolated from a cattle-dipping tank. South African J Sci 14, 465-467.

Hanaoka, K. T., Matsumoto, S., Tagawa, S. \& Kaise, T. (1987). Microbial degradation of arsenobetaine, the major water-soluble organoarsenic compound occurring in marine animals. Chemosphere 16, 2545-2550.

Hanaoka, K. T., Hasegawa, S., Kawabe, N., Tagawa, S. \& Kaise, T. (1991). Aerobic and anaerobic degradation of several arsenicals by sedimentary microorganisms. Appl Organomet Cbem 4, 239-243.

Hanaoka, K. T., Tagawa, S. \& Kaise, T. (1992). The degradation of arsenobetaine to inorganic arsenic by sedimentary microorganisms. Hydrobiologia 235/236, 623-628.

Ji, G. \& Silver, S. (1992). Reduction of arsenate to arsenite by the
ArsC protein of the arsenic resistance operon of Staphylococcus aureus plasmid pI258. Proc Natl Acad Sci US A 89, 9474-9478.

Krieg, N. R. (1981). Enrichment and isolation. In Manual of Methods for General Bacteriology, pp. 112-142. Edited by P. Gerhardt, R. G. E. Murray, R. N. Costilow, E. W. Nester, W. A. Wood, N. R. Krieg \& G. B. Phillips. Washington, DC: American Society for Microbiology.

Lacoste, A.-M., Dumora, C., Ali, B. R. S., Neuzil, E. \& Dixon, H. B. F. (1992). Utilization of 2-aminoethylarsonic acid in Pseudomonas aeruginosa. J Gen Microbiol 138, 1283-1287.

McMullan, G. \& Quinn, J. P. (1994). In vitro characterization of a phosphate starvation-independent carbon-phosphorus bond cleavage activity in Pseudomonas fluorescens 23F. J Bacteriol 176, 320-324.

McMullan, G., Watkins, R., Harper, D. B. \& Quinn, J. P. (1991). Carbon-phosphorus bond cleavage activity in cell-free extracts of Enterobacter aerogenes ATCC 15038 and Pseudomonas sp. 4ASW. Biochem Int 25, 271-279.

Metcalf, W. W. \& Wanner, B. L. (1991). Involvement of the Escherichia coli phn ( $p$ siD) gene cluster in assimilation of phosphorus in the form of phosphonates, phosphite, $\mathrm{P}_{\mathrm{i}}$ esters and $\mathrm{P}_{\mathrm{i}} . J$ Bacteriol $173,587-600$.

Osborne, F. H. \& Ehrlich, H. L. (1976). Oxidation of arsenite by a soil isolate of Alcaligenes. J Appl Bacteriol 41, 295-305.

Phillips, S. E. \& Taylor, M. L. (1976). Oxidation of arsenite to arsenate by Alcaligenes faecalis. Appl Environ Microbiol 32, 392-399. Quick, A. J. \& Adams, R. (1922). Aliphatic arsonic and arsinic acids, and aliphatic-aromatic arsinic acids. $J \mathrm{Am}$ Chem Soc 44, 805-816.

Segers, P., Vancanneyt, M., Pot, B., Torck, U., Hoste, B., Dewettinck, D., Falsen, E., Kersters, K. \& De Vos, P. (1994). Classification of Pseudomonas diminuta Leifson and Hugh 1954 and Pseudomonas vesicularis Büsing, Döll and Freytag 1953 in Brevundimonas diminuta comb. nov. and Brevundimonas vesicularis comb. nov. respectively. Int J Syst Bacteriol 44, 499-510.

Sehlin, H. M. \& Lindstrom, E. B. (1992). Oxidation and reduction of arsenic by Sulfolobus acidocaldarius strain BC. FEMS Microbiol Lett 93, 87-92.

Shariatpahani, M., Anderson, A. C., Abdelghani, A. A. \& Englande, A. J. (1983). Microbial metabolism of an organic arsenical herbicide. In Biodeterioration 5, pp. 268-277. Edited by T. A. Oxley \& S. Barry. Chichester: John Wiley.

Sparkes, M. J. \& Dixon, H. B. F. (1995). Preparation of substituted methylarsonic and arsonoacetic acids. [Appendix to this paper.] Microbiology 141, 726-727.

Tamaki, S. \& Frankenberger, W. T. (1992). Environmental biochemistry of arsenic. Rev Environ Contam Toxicol 124, 79-110.

Thayer, J. S. (1993). Global bioalkylation of the heavy elements. Metal Ions Biol Syst 29, 1-36.

Turner, A. W. \& Legge, J. W. (1954). Bacterial oxidation of arsenite. 2: The activity of washed suspensions. Aust J Biol Sci 7, 479-495.

Von Endt, D. W., Kearney, P. C. \& Kaufman, D. D. (1968). Degradation of monosodium methanearsonic acid by soil microorganisms. J Agric Food Chem 16, 17-20.

Wanner, B. L. \& Metcalf, W. W. (1992). Molecular studies of a $10.9-\mathrm{kb}$ operon in Escherichia coli for phosphonate uptake and biodegradation. FEMS Microbiol Lett 100, 133-140.

Williams, J. W. \& Silver, S. (1984). Bacterial resistance and detoxification of heavy metals. Enzyme Microb Technol 6, 530-537.

Received 25 July 1994; revised 7 November 1994; accepted 22 November 1994. 


\title{
APPENDIX
}

\section{Preparation of substituted methylarsonic and arsonoacetic acids}

\author{
Michael J. Sparkes and Henry B. F. Dixon
}

Department of Biochemistry, University of Cambridge, Tennis Court Road, Cambridge CB2 1QW, UK

\begin{abstract}
Arsonochloroacetic acid $\left(\mathrm{HOOC}-\mathrm{CHCl}-\mathrm{AsO}_{3} \mathrm{H}_{2}\right)$ has been synthesized by the action of alkaline arsenite on dichloroacetic acid; chloromethylarsonic acid $\left(\mathrm{Cl}-\mathrm{CH}_{2}-\mathrm{AsO}_{3} \mathrm{H}_{2}\right)$ was obtained from it by decarboxylation. Bromination of arsonoacetic acid yielded dibromomethylarsonic acid $\left(\mathrm{Br}_{2} \mathrm{CH}-\mathrm{AsO}_{3} \mathrm{H}_{2}\right)$.
\end{abstract}

For comparison with arsonoacetic acid we have prepared arsonochloroacetic acid; we have also made its decarboxylation product, chloromethylarsonic acid, as well as the related dibromomethylarsonic acid. When we applied the Meyer (1883) reaction (alkaline arsenite with an alkyl halide) to dichloroacetate we obtained arsonochloroacetic acid; standard conditions for decarboxylating arsonoacetic acids (Adams et al., 1984) converted it into chloromethylarsonic acid. Bromination of arsonoacetic acid proved to lead directly to decarboxylation, and dibromomethylarsonic acid was obtained. As noted for chloromethylphosphonic acid (Schwarzenbach et al., 1949 , p. 1185), we found that halide is difficult to displace from a 1-haloalkylarsonic acid. This is presumably because the staggering of the halomethyl and the arsono or phosphono groups places one of the oxygen atoms of the $-\mathrm{XO}_{3}^{2-}$ group antiperiplanar to the halogen atom, so that this oxygen hinders approach of a displacing nucleophile.

\section{EXPERIMENTAL}

\section{Paper electrophoresis}

This was performed on papers cooled by immersion in white spirit, in the system of Ambler (1963). Arsonic acids were detected on papers by the method of Wade \& Morgan (1953) for phosphates, i.e. by their binding $\mathrm{Fe}^{3+}$ and so removing the colour of its complex with sulphosalicylic acid.

\section{Arsono(chloro)acetic acid ( $\mathrm{HOOC}-\mathrm{CHCl}-\mathrm{AsO}_{3} \mathrm{H}_{2}$ ), bis(cyclohexylammonium) salt}

Sodium hydroxide $(14 \mathrm{~g}, 350 \mathrm{mmol})$ was dissolved in $25 \mathrm{ml}$ water and to the hot solution arsenic(III) oxide (5 g, $50 \mathrm{mmol} \mathrm{As}$ ) was added. When it had dissolved, $4.1 \mathrm{ml}$ dichloroacetic acid $(6.5 \mathrm{~g}, 50 \mathrm{mmol})$ was added with stirring. After the mixture had stood overnight while it cooled to room temperature, paper electrophoresis at $\mathrm{pH} 2$ showed that the main $\mathrm{Fe}^{3+}$-binding spot had about 2.7 times the mobility of arsenate. To the mixture was added $25 \mathrm{ml}$ water and the slurry was filtered. A solution of $18.5 \mathrm{~g} \mathrm{BaCl}_{2}$ in $50 \mathrm{ml}$ hot water was added to the filtrate. A thick precipitate formed; after $30 \mathrm{~min}$ this was filtered off and washed with $25 \mathrm{ml}$ water. It was then suspended in water and $75 \mathrm{ml}$ of the acid form of the sulfonic resin Dowex 50X8 was added and stirred until the precipitate dissolved. The suspension was poured onto a column of more of this resin and washed through with water. The resulting solution was applied to a column $(27 \times 2.3 \mathrm{~cm})$ of Dowex-1X8 in the chloride form. The column was washed with $500 \mathrm{ml}$ (five column volumes) of water, and the effluent, which contained two contaminants (of lower mobility on paper electrophoresis and giving the $\mathrm{Fe}^{3+}$-binding test), was discarded. The column was then eluted with $110.1 \mathrm{M} \mathrm{HCl}$, and the effluent was evaporated to dryness, re-evaporated once after addition of water, and desiccated overnight over $\mathrm{NaOH}$, to remove $\mathrm{HCl}$. The remaining oil was dissolved in water, adjusted to $\mathrm{pH} 6$ with cyclohexylamine, and evaporated to dryness, and re-evaporated after addition of methanol. The oily solid was dissolved in $50 \mathrm{ml}$ methanol, and on addition of $150 \mathrm{ml}$ diethyl ether the product crystallized overnight. Yield $5.1 \mathrm{~g}$ (24.5\%). M.p. $148-150{ }^{\circ} \mathrm{C}$. Elemental analysis gave $\mathrm{C}, 40.36 \% ; \mathrm{H}$, $7.26 \% ; \mathrm{N}, 6.63 \% . \mathrm{C}_{2} \mathrm{H}_{4} \mathrm{AsClO}_{5} .2 \mathrm{C}_{6} \mathrm{H}_{13} \mathrm{~N}$ requires $\mathrm{C}$, $40.35 \% ; \mathrm{H}, 7.26 \%$; N, $6.72 \%$.

Chloromethylarsonic acid $\left(\mathrm{Cl}-\mathrm{CH}_{2}-\mathrm{AsO}_{3} \mathrm{H}_{2}\right)$, cyclohexylammonium salt

Arsono(chloro)acetic acid was liberated from its bis(cyclohexylammonium) salt $(2 \mathrm{~g})$ by dissolving in water and passing through a column of the acid form of the sulfonic resin Dowex 50X8. It was then evaporated to dryness, leaving an oil. This was dissolved in $5 \mathrm{ml}$ water, and to this was added $200 \mathrm{ml} \mathrm{n}$-propanol. The propanolwater azeotrope was distilled off, up a fractionating column, until the temperature of the vapour reached the boiling point of propanol. The remaining solution was boiled under reflux for $30 \mathrm{~min}$ to decarboxylate it (Adams et al., 1984). Paper electrophoresis showed a greatly diminished mobility at $\mathrm{pH} 2$. The solution was evaporated to dryness; the residue was dissolved in water, adjusted to pH 6 with cyclohexylamine, evaporated to dryness, and re-evaporated after addition of methanol. The product was dissolved in $12 \mathrm{ml}$ methanol, and crystallized on addition of $30 \mathrm{ml}$ diethyl ether. Yield $0.9 \mathrm{~g}(68 \%$ ) (a further $0.2 \mathrm{~g}$ crystallized on addition of more ether, making a total yield of $84 \%$ ). M.p. $164-166{ }^{\circ} \mathrm{C}$. Elemental analysis gave $\mathrm{C}, \quad 30.3 \% ; \mathrm{H}, 6.3 \% ; \mathrm{N}, \quad 5.0 \%$. 
$\mathrm{CH}_{4} \mathrm{AsClO}_{3} . \mathrm{C}_{6} \mathrm{H}_{13} \mathrm{~N}$ requires $\mathrm{C}, 30.7 \% ; \mathrm{H}, 6.3 \% ; \mathrm{N}$, $5 \cdot 1 \%$. The electrophoretic mobility at $\mathrm{pH} 2$ was 0.37 that of arsenate $(0 \cdot 15$ that of arsono(chloro)acetic acid).

\section{Arsonoacetic acid $\left(\mathrm{HOOC}-\mathrm{CH}_{2}-\mathrm{AsO}_{3} \mathrm{H}_{2}\right)$}

This was made by the Meyer (1883) reaction of treating chloroacetic acid with alkaline arsenite (Palmer, 1925), and the barium salt was converted into the free acid as described by Rozovskaya et al. (1984).

\section{Dibromomethylarsonic acid $\left(\mathrm{Br}_{2} \mathrm{CH}-\mathrm{AsO}_{3} \mathrm{H}_{2}\right)$}

Arsonoacetic acid $(4.5 \mathrm{~g}, 24 \mathrm{mmol})$ was dissolved in a mixture of $20 \mathrm{ml}$ water and $20 \mathrm{ml}$ acetic acid. Bromine $\left(2.6 \mathrm{ml}, 50 \mathrm{mmol} \mathrm{Br}_{2}\right)$ was added and dissolved in the mixture. After a lag it largely decolorized and the solution effervesced. After the mixture had stood overnight, paper electrophoresis showed the presence of an arsenatepositive spot of greater mobility at $\mathrm{pH} 2$ than the starting compound. The solution was added to a column of $29 \mathrm{~cm} \times 2.6 \mathrm{~cm}$ of the strongly basic resin Dowex $1 \mathrm{X} 8$ in the acetate form, which was washed with $100 \mathrm{ml}$ water, and $500 \mathrm{ml}$ portions of $5 \mathrm{M}$ formic acid and $10 \mathrm{M}$ formic acid. The last of these was evaporated to dryness and the product crystallized. The solid was dissolved in ethyl acetate, and the solution was dried over sodium sulphate, filtered, and evaporated to dryness. The resulting solid was dissolved in ethyl acetate and crystallized on adding light petroleum. Yield: $5.2 \mathrm{~g}(63 \%)$. M.p. $142-144{ }^{\circ} \mathrm{C}$. Elemental analysis gave C, 4.01\%; H. $1 \cdot 00 \%$. $\mathrm{CH}_{3} \mathrm{AsBr}_{2} \mathrm{O}_{3}$ requires $\mathrm{C}, 4.03 \% ; \mathrm{H}, 1.02 \%$. Titration of a portion in water showed one $\mathrm{p} K$ to be below 3 , and the other about 6.7. A solution of the acid in aqueous ammonia (density $0.88 \mathrm{~g} \mathrm{ml}^{-1}$ ) was unchanged, as judged by paper electrophoresis, after $3 \mathrm{~d}$ at $20^{\circ} \mathrm{C}$; this unreactivity is similar to that of chloromethylphosphonic acid reported by Schwarzenbach et al. (1949, p. 1185).

\section{REFERENCES}

Adams, S. R., Sparkes, M. J. \& Dixon, H. B. F. (1984). The arsonomethyl analogue of adenosine $5^{\prime}$-phosphate. Biochem J 221, 829-836.

Ambler, R. P. (1963). The amino acid sequence of Pseudomonas cytochrome $c$-551. Biochem $J$ 89, 349-378.

Meyer, G. (1883). Ueber einige anomale Reaktionen. Ber Dtsch Chem Ges 16, 1439-1443.

Palmer, C. S. (1925). Arsono- and arsenoacetic acids. Org Synth 4, 5-7 (Org Synth Coll vol. 1, pp. 66-67).

Rozovskaya, T. A., Rechinsky, V. O., Bibilashvili, R. Sh., Karpeisky, M. Ya., Tarusova, N. B., Khomutov, R. M. \& Dixon, H. B. F. (1984). The mechanism of pyrophosphorolysis of RNA by RNA polymerase. Biochem J 224, 645-650.

Schwarzenbach, G., Ackermann, H. \& Ruckstuhl, P. (1949). Neue Derivate der Iminodiessigsäure und ihre Erdalkalikomplexe. Beziehungen zwischen Acidität und Komplexbildung. Helv Chim Acta 32, 1175-1186

Wade, H. E. \& Morgan, D. M. (1953). Detection of phosphate esters on paper chromatograms. Nature 171, 529-530.

Received 25 July 1994; revised 7 November 1994; accepted 22 November 1994. 